\title{
SOCIAL CAPITAL, TOO MUCH OF A GOOD THING? AMERICAN RELIGIOUS TRADITIONS AND COMMUNITY CRIME**
}

\author{
Kraig Beyerlein and John R. Hipp \\ Department of Sociology \\ University of North Carolina at Chapel Hill \\ Post-print: Published in Social Forces (2005) 84(2): 995-1013. Definitive version available at \\ http://sf.oxfordjournals.org/content/84/2/995.abstract?sid=ab661de4-8a20-49a2-b26f-d74050c4fe9b
}

Running Head: "Social Capital, Too Much of a Good Thing?"

\begin{abstract}
*Order of authorship is alphabetical to denote equal contribution. We thank Christian Smith, Kenneth Bollen, anonymous reviewers, and the editor for helpful comments on earlier drafts of this article. An earlier version of this article received the 2004 Best Graduate Student Paper Award from the Community and Urban Sociology (CUSS) and Crime, Law, and Deviance (CLD) Sections of the American Sociological Association, and the 2004 Best Graduate Student Paper Award from the Crime and Juvenile Delinquency (CJD) Division of the Society for the Study of Social Problems. Direct correspondence to Kraig Beyerlein or John R. Hipp at the Department of Sociology, University of North Carolina at Chapel Hill, Hamilton Hall, CB \#3210, Chapel Hill, NC 27599. Emails: kkbeyerl@email.unc.edu and johnhipp@email.unc.edu.
\end{abstract}




\title{
SOCIAL CAPITAL, TOO MUCH OF A GOOD THING? AMERICAN RELIGIOUS TRADITIONS AND COMMUNITY CRIME
}

\begin{abstract}
Using American religious traditions as measures of bonding and bridging social capital in communities, we empirically test how these different forms of social capital affect crime rates in 3,157 U.S. counties in 2000. Our results suggest that the bonding networks evangelical Protestants promote in communities explain why counties with a greater percentage of residents affiliated with this tradition consistently have higher crime rates. Conversely, our results suggest that the bridging networks mainline Protestants and Catholics foster in communities explain why counties with a greater percentage of residents affiliated with these traditions generally have lower crime rates. This article provides empirical corroboration for recent theoretical discussions that focus on how the social capital groups cultivate in communities need not always benefit communities as a whole.
\end{abstract}




\section{SOCIAL CAPITAL, TOO MUCH OF A GOOD THING? AMERICAN RELIGIOUS TRADITIONS AND COMMUNITY CRIME}

Few concepts in the social sciences have received more scholarly attention and public notoriety over the past decade than social capital. When conceptualized as networks that link individuals and the resources embedded in those linkages, social capital has substantially enhanced our understanding of various social processes and outcomes. The majority of research on social capital has focused on its positive benefits. Among other things, this research has shown that social capital promotes social support, boosts physical health, improves academic performance, and increases job contacts (Granovetter 1985; Hurlbert, Haines, and Beggs 2000; Pong 1998). However, the tendency to focus on social capital's positive effects has recently drawn a chorus of criticism from scholars who point out that social capital need not necessarily produce positive consequences, and that it may even produce negative results (Fiorina 1999; Paxton 1999, 2002; Portes 1998; Putnam 2000).

Social capital by definition benefits those who possess it. Yet there is good reason to believe that the advantages individuals accrue from social capital often come at the expense of others. For instance, while strongly knit groups provide various benefits to members, their general exclusivity restricts entry to others and denies benefits to nonmembers (Portes 1998). Strongly knit groups can also have deleterious consequences for the wider community in which they reside. Consider militia groups that have strong internal ties but very few or no external ties in communities. Their intense within-group solidarity provides numerous benefits to members, such as emotional support or a sense of belonging. However, because militia groups do not forge connections with other residents, they truncate the wider network structure of the community and thus decrease its overall cohesiveness (Paxton 1999).

This problematizes viewing social capital as a homogenous concept at one level of aggregation, and points to the importance of distinguishing types of social capital and the differing effects they can have at different levels of aggregation. We differentiate bonding social capital in which linkages are mainly or exclusively among members of the same group from bridging social capital in which linkages exist among members of different groups in communities (Paxton 1999, 2002; Putnam 2000). Although bonding groups increase social capital within the level of their group, they can reduce social capital at the 
community level, as the above example of militia groups illustrates. On the other hand, bridging groups that establish connections with others outside their group increase social capital at the community level by expanding the overall network structures of the communities in which they are embedded.

To the extent that community cohesion and connectedness influence the incidence of crime (Lee 2000; Sampson, Raudenbush, and Earls 1997), the type of social capital that groups foster in communities should be of considerable importance for explaining differences in crime rates across communities. We do not assume, however, that members of bonding and bridging groups are committing crimes in communities or that they are doing so at different rates. We rather argue that groups exhibiting bonding social capital will be less effective in generating network structures that help the larger community deal with the threat of crime, while groups exhibiting bridging social capital will be more effective in creating these network structures. Importantly, by providing an empirical test of this hypothesis, we substantially advance the literature on social capital.

Providing an empirical test of the differing effects of bonding and bridging groups on community-level outcomes is a challenge due to the difficulty of measuring these types of social capital. Adequately measuring bonding and bridging social capital requires capturing entire network structures of communities, a daunting task for researchers. An alternative strategy utilizes measures that serve as proxies for these concepts, and recent scholarship in the sociology of religion generally demonstrates the division of American major religious traditions into bonding and bridging camps (Ammerman 2002; Beyerlein and Hipp 2003; Chaves, Giesel, and Tsitsos 2002; Iannaccone 1994; Putnam 2000; Wilson and Janoski 1995; Wuthnow 1999, 2002). Consequently, religious traditions are one way to operationalize bonding and bridging groups in communities and to test whether these types of social capital have differing effects on communities' crime rates.

\section{LINKING BONDING AND BRIDGING SOCIAL CAPITAL TO COMMUNITY CRIME}

Although scholars have defined social capital in various ways, we conceptualize social capital as network structures linking individuals in communities (Coleman 1988; Paxton 1999; Putnam 2000). Because network structures vary in the extent to which they narrowly or broadly link residents in communities, it 
is important to differentiate bonding social capital from bridging social capital. Bonding social capital consists of network structures in which connections are primarily or entirely among members of the same group, while bridging social capital consists of network structures in which connections crosscut members of different groups (Putnam 2000). Ties comprising bonding social capital tend to be stronger in nature, while ties comprising bridging social capital tend to be weaker in nature (Granovetter 1973). While not using the language of bonding and bridging social capital, scholars working within the social disorganization tradition have suggested that such differences in network structures are important for explaining variation in crime rates across communities. Bellair (1997) focused on infrequent interaction among neighbors, theorizing that because infrequent interaction is more likely to occur among a greater percentage of residents than frequent interaction, it plausibly reflects a wider constellation of ties within the larger community and thus a more disperse overall network structure. He observed that even with frequent interaction — “strong ties"- among residents, without infrequent interaction- “weak ties"as well, communities will be partitioned and disorganized since a large portion of residents will not be connected in any way (see also Granovetter 1973). Because broad-based network structures increase the degree of interconnectedness among residents in communities, they should facilitate the diffusion of information and collective social control efforts. As Bellair (1997:683) states, "communities with extensive networks are assumed to be more integrated and cohesive, and the residents more likely to engage in informal surveillance, to develop movement-governing rules, and to intervene in disturbances." Empirically, Bellair (1997) identified that progressively less frequent interaction among neighbors generally had a strong negative effect on various types of crime. Other empirical evidence also suggests that broader network linkages may help depress the incidence of crime in communities. For instance, Taylor, Gottfredson, and Brower (1984) showed that communities with a greater proportion of residents who shared organization memberships had lower rates of violent crime, and Sampson and Groves (1989) observed that the combination of friendship networks and acquaintanceship networks resulted in consistently lower rates of various types of community crimes than friendship networks alone. Conversely, in communities where residents are not broadly linked, supervision, guardianship, and informal efforts to promote community goals are likely to be weak (Freudenburg 1986; Jacobs 1961). 
Importantly, bonding groups should hinder the formation of broad network structures that allow communities to mobilize effectively to protect collective interests. As Sampson and Raudenbush (1999:612) articulate, "personal ties and friendship are not sufficient; the private world of strong kinship ties may actually interfere with public trust and expectation of collective responsibility for getting things done." Bonding network structures are thus likely to increase crime rates in communities by reducing collective efficacy or the sense that others will participate and respond to problems (Sampson, Morenoff, and Earls 1999; Sampson and Raudenbush 1999; Sampson et al. 1997). Sampson and colleagues have consistently shown that collective efficacy has a significant inverse effect on disorder and crime (see also Lee 2000). Where bonding network structures are pervasive, the lack of linkages among groups in communities should weaken collective efficacy, making communities more vulnerable to crime. ${ }^{1}$

The above summary of the social capital and social disorganization literature indicates that the bonding and bridging network structures that groups create in communities should have opposite effects on communities' crime rates. While bonding social capital should increase crime rates in communities, bridging social capital should decrease them. This challenges the notion that the social capital that groups cultivate in communities will always benefit communities as a whole. However, no research to date has operationalized bonding and bridging social capital and tested whether they have these posited effects on crime rates. Recent studies on the relationship between social capital and crime invariably treat social capital as a homogenous concept, captured in different measures, that is always theorized to reduce crime in communities (Messner, Baumer, and Rosenfeld 2004; Putnam 2000; Rosenfeld, Messner, and Baumer 2001). For example, Rosenfeld et al. (2001) operationalized social capital as a latent construct, using measures of social trust and civic engagement as indicators, and found that social capital decreased the homicide rate in 99 geographic areas similar to SMSA's throughout the United States. As valuable as such studies are, they did not distinguish between bonding and bridging social capital, and thus they cannot answer the important question of whether these different types of social capital have differing effects on crime rates. 


\section{RELIGIOUS TRADITIONS AS MEASURES OF BONDING AND BRIDGING SOCIAL}

\section{CAPITAL}

An ideal test of our theoretical model would collect and analyze data on the entire network structure of a large number of communities. Given that this is an impractical task, we employed a measure that approximates the entire network structure of communities. Considerable literature in the sociology of religion documents that American religious traditions are such a measure. Because of contrasting theological orientations, adherents of the different major U.S. religious traditions behave in ways that give rise to very different network structures in communities. As Putnam (2000:77-78) summarizes “...[today's] evangelicals are more likely to be involved in activities within their own religious community but are less likely to be involved in the broader community...[while] today's mainline Protestants and Catholics are more likely to be involved in volunteering and service in the wider community."

A large body of research has shown that because of their emphasis on otherworldly pursuits, evangelical Protestants tend to participate exclusively in activities and groups in their own congregations or other religious organizations consisting of fellow believers (Hoge et al. 1998; Wuthnow 2002). For instance, using the General Social Surveys (GSS) from 1984 to 1990, Iannacone (1994) found considerable differences among Protestants in belonging to church-affiliated groups. Splitting Protestant traditions into four categories of varying conservatism/liberalism, he found that members of the most conservative traditions were 31 percent more likely than were members of the most liberal traditions to belong to church-affiliated groups. Using the Giving and Volunteering Surveys from the Independent Sector, Wuthnow (1999) reported that the majority of volunteer work in which evangelical Protestants engage is focused on the religious life of their congregations, such as teaching Sunday school or assisting pastors. Based on similar evidence, Wilson and Janoski (1995:149-50) concluded that "conservative Protestants do volunteer work more if they are integrated into the church, but what they volunteer for is church maintenance work."

On the other hand, mainline Protestant and Catholic traditions stress that believers should engage the broader community and help those outside of their religious groups. Numerous studies have shown 
that mainline Protestants and Catholics participate in various activities and organizations that serve the needs of and establish connections with others in the wider community (Beyerlein and Hipp 2003; Wilson and Janoski 1995; Wuthnow 2002, 2004). For instance, in his analysis of the Giving and Volunteering Surveys, Wuthnow (1999) demonstrated that the more frequently mainline Protestants and Catholics participated in churches, the more likely they were to not only volunteer for religious organizations, but also for organizations focused on improving communities, providing medical assistance to the needy, and helping struggling students. Wuthnow (1999), however, found no such effects for evangelical Protestants. In his study using GSS data from 1984 to 1990, Iannacone (1994) found that members of the most liberal Protestant traditions belonged to 50 percent more nonreligious organizations than members of moderately conservative traditions, and twice as many nonreligious organizations as members of the most conservative traditions.

Given these religious tradition differences in bonding and bridging activity, we expect that a greater percentage of mainline Protestants and Catholics will decrease crime rates in communities, while a greater percentage of evangelical Protestants will increase these rates. By participating in activities and organizations that link them to others in their broader environment, mainline Protestants and Catholics foster bridging network structures and thus their greater presence in communities should reduce crime for communities as a whole. Conversely, by generally participating in activities and organizations that consist exclusively of their own people, evangelical Protestants promote bonding network structures and thus their greater presence in communities should increase crime for communities as a whole.

Since we focus on religious traditions as measures of network structures of communities instead of theorizing about the delinquency of individuals, our conceptual approach to studying religion and crime diverges from past research on this topic. More individualistic-based theories have suggested that religious individuals engage in less delinquent activity (see, for example, Evans et al. 1995; Johnson et al. 2001; Sloane and Potvin 1986), especially when surrounded by a high proportion of fellow believers (Stark 1996; Stark, Kent, and Doyle 1982). Note that these theories never predict that the number of adherents of different religious traditions will have differing effects on crime rates of communities, nor do they predict that any of these adherents will increase crime rates. Ellison, Burr, and McCall (2003) 
focused on evangelical Protestantism and posited that because its culture in the South strongly supports punitive responses to criminal offences, a greater presence of evangelical Protestants in Southern communities creates a cultural environment that is conducive to violent crime. However, this explanation is questionable theoretically on at least two grounds. First, other theological orientations of evangelical Protestantism would seem to nurture a cultural atmosphere that reduces crime, such as the emphasis on strong and caring families (Wilcox 2004). Second, Rosenfeld et al. (2001) found that the higher rates of homicide in the South were generally a function of the lack of social capital in this region. This explanation is also questionable empirically since Ellison et al. (2003) used a unit of analysis that is arguably too large (SMSA's), did not fully interpret their parameterization, and did not perform a statistical test of this hypothesis. ${ }^{2}$

More akin to our theoretical approach is Lee and Bartkowski's (2004) recent study showing that the proportion of people in counties who were members of civically engaged denominations had a negative effect on family related juvenile homicide in rural counties. While valuable, Lee and Bartkowski's (2004) use of Tolbert, Lyson, and Irwin's (1998) measure of membership in any type of voluntary organization rather than membership in bridging organizations to classify civically engaged denominations may explain their nonsignificant findings for urban counties and other types of juvenile homicide. Moreover, by focusing exclusively on civically engaged denominations, they did not consider how the bonding activity of certain religious groups possibly constricts the larger network structures of communities and thus increases communities' crime risk.

\section{RELIGIOUS CONGREGATIONS AND COMMUNITY CRIME}

The social disorganization perspective has long emphasized the importance of organizations for combating crime in communities. Organizations increase awareness of various community problems, and they have formal resources that facilitate solving community problems, such as the direct provision of services to people who are in need (Kornhauser 1978; Shaw and McKay 1942). Some have speculated that to the extent that various organizations coordinate and pool their resources, they will be even more effective in reducing disorder and crime in communities (Mesch and Schwirian 1996; Morenoff and 
Sampson 1997). Prior research has shown that the congregations of all the major American religious traditions engage in various social service programs in communities, though mainline Protestant and Catholic congregations tend to be more engaged in these programs than evangelical Protestant congregations (Ammerman 2002; Chaves 2004; Chaves et al. 2002; Chaves and Tsitsos 2001; Wuthnow 2004). In contrast to adherents of the different religious traditions, then, because congregations of the different religious traditions all tend to provide resources to communities, they should have similar negative effects on crime rates. Because of the strong institutional base that congregations establish in communities, it is imperative to control for them when modeling the effect of adherents on crime in communities. Without accounting for the institutional resources of religious traditions, it is not possible to isolate the network effect of their adherents.

\section{DATA}

We constructed our data from a variety of sources. Since focusing on small neighborhoods may not capture the effects of social networks among residents across neighborhoods, we used counties as our unit of analysis. For the dependent variables, we used reports of offenses for specific crime types from the Uniform Crime Report (UCR) for 1998-2000. ${ }^{3}$ Although there has been considerable discussion regarding the use of official reports of crimes, we focused on crime that has minimal reporting inconsistencies - murder - and other types that have shown the most consistency with victimization surveys - aggravated assault, robbery, and burglary (Cohen and Land 1984; Gove, Hughes, and Geerken 1985). Since both robbery and aggravated assault are violent crimes that have a particularly frightening effect on individuals, we combined them into a single measure. ${ }^{4}$ We calculated these crime rates per 100,000 population, and log-transformed them to obtain a more normal distribution.

The religious tradition data come from the 2000 Glenmary Survey of American religious adherents and congregations (Jones et al. 2002). This decennial survey of religious organizations estimates both the number of adherents and the number of congregations in a county for 149 denominations in the United States. We used this information to distinguish Catholic, mainline Protestant, and evangelical Protestant adherents and congregations. Using Steensland et al. (2000) and 
Melton (2002) as resources, we classified Protestant denominations either as mainline or evangelical (see online appendix Table A1 at http://www.unc.edu/ johnhipp/religcri.htm for a complete list of the denominations classified in each category). We classified those not fitting into one of these three religious traditions as other. ${ }^{5}$ To capture bonding networks in counties, we calculated the proportion of the county population composed of evangelical Protestant adherents. We used two measures to capture bridging network structures in counties: the proportion of the county population composed of mainline Protestant adherents and the proportion of the county population composed of Catholic adherents. As a measure of the institutional resources that religious traditions provide to counties, we calculated the number of congregations per 100,000 people for each religious tradition.

To minimize the possibility of spurious findings, we included numerous variables that past criminological research has found to predict crime in communities, constructed from the 2000 U.S. Bureau of the Census STF-3A files. Four measures that likely affect both the crime rate and the religious composition of communities are population density, Southern residence, racial composition, and socioeconomic status. We therefore included a measure of the population density per kilometer, a dummy variable for counties in states in the traditional South, and measures of the percent AfricanAmerican, Latino, and white, with Asian and other racial groups as the omitted category. To capture SES effects, we included a measure of the education level in the community (the percent who hold at least a bachelor's degree), the percent of the population with an income at or below the poverty level, and both the median household income and the median household income squared to capture possible nonlinear effects of income.

We also included three other measures that past research has found to be associated with crime rates. Note that doing so provides a stringent test of the network effects we posit for adherents of the various religious traditions since we are controlling for other ways through which these adherents may affect crime. To capture communities with limited adult supervision, we included the percentage of single parent families in the county. Since the social disorganization model posits that residential instability of communities should affect the social networks within them, we included a measure of the average length of time residents have lived in their current homes. Finally, to account for the possible 
increase in offenders, we included a measure of the county unemployment rate. Since our indicators are measured per capita, we included the inverse of population in our models (Firebaugh and Gibbs 1985). We present the descriptive statistics for the variables used in our analyses in Table $1 .{ }^{6}$

[INSERT TABLE 1 ABOUT HERE]

\section{MODELING STRATEGY}

We used ordinary least squares (OLS) regression to estimate models for our three crime outcomes. $^{7}$ By using data on nearly all available U.S. counties, we minimized the likelihood of sample selection bias (Heckman 1979). Studies that include only large MSAs or central cities are particularly susceptible to this bias because these locations are where crime rates are the highest (Kovandzic, Vieratis, and Yeisley 1998). As Berk (1983) showed, studies that select samples based on their relationship to the dependent variable run the risk of having biased coefficients. Additionally, this strategy allows us to generalize our findings to all counties in the United States. We used multiple imputation to handle missing data, allowing us to make the less strict assumption that our data are missing at random (MAR), not the stronger assumption that they are missing completely at random (MCAR), which is necessary when employing listwise deletion (Allison 2002; Schafer and Graham 2002).

For each of our three crime measures we first estimated models with the proportion of the county population composed of adherents of each religious tradition, along with our control variables. While this model does not control for the institutional resources of the religious traditions, it gives us a baseline model on which to build. We next estimated models in which we replaced the measures of adherents of each religious tradition with measures of the number of congregations of each religious tradition. This allowed us to assess the social disorganization theory that the institutional resources associated with each of the religious tradition's congregations should similarly reduce crime rates in communities. Finally, we estimated a model in which we simultaneously entered adherents and congregations of each religious tradition with our control variables. This full model enabled us to assess whether the different network structures that the adherents of religious traditions foster in communities affect crime rates net of the 
institutional resources that their congregations provide as well as numerous other variables shown in prior studies to be important predictors of ecological crime rates.

\section{RESULTS}

We begin by viewing the effects of adherents of different religious traditions on the combined aggravated assault/robbery measure. All models control for the demographic variables described above, but to conserve space we do not report their results in Table 2 (see Table A4 in the online appendix at http://www.unc.edu/ johnhipp/religcri.htm). In the first model, when we do not control for the institutional resources of the religious traditions, there is evidence that counties with more Catholic and mainline Protestant adherents have lower logged rates of assault/robbery. A one percentage point increase in Catholic adherents in a county reduces the assault/robbery rate by 0.3 percent, while an analogous increase in the percentage of mainline Protestants reduces this rate by 1.8 percent, as seen in model 1 in Table $2{ }^{8}$ These results are consistent with our hypothesis that the bridging activity of Catholics and mainline Protestants reduces crime rates in communities. In contrast, we see that an increase in the proportion of evangelical Protestant adherents is associated with higher assault/robbery rates. For a one percentage point increase in evangelical Protestant adherents, the assault/robbery rate increases by 0.8 percent.

\section{[INSERT TABLE 2 ABOUT HERE]}

To view the institutional effects of the religious traditions, we next estimate a model in which we replace the measures of adherents with measures of congregations of each tradition. We see in model 2 of Table 2 that Catholic and mainline Protestant congregations significantly reduce the assault/robbery rate in counties. Note that while evangelical Protestant adherents are associated with higher rates of assault/robbery in model 1 , the effect of their congregations is not significant. This suggests that adherents and congregations are capturing distinct constructs, and underscores the need to disentangle their effects by including them both in a single model.

We therefore next estimate our full model in which we include both adherents and congregations of each religious tradition. This model provides consistent support for our posited bonding and bridging 
network effects on crime rates in communities. We see evidence of the hypothesized bridging network effect of mainline Protestants in model 3 of Table 2, as an increase in the proportion of adherents of this tradition is associated with lower logged assault/robbery rates in counties. Specifically, a one percentage point increase in mainline Protestant adherents is associated with a 1.3 percent reduction in the assault/robbery rate. Note that we obtain this result while controlling for the presence of congregations, as well as a host of other important variables shown in the criminological literature to affect crime rates in communities. The effect of Catholic adherents is also in the expected direction, though it does not reach significance at conventional levels. We stress that these findings are not simply "religious" effects, as in this same model a one percentage point increase in evangelical Protestant adherents is associated with 0.9 percent increase in the assault/robbery rate. This is consistent with our argument that while bonding together and withdrawing from the larger community provides various benefits to group members, this behavior can have deleterious effects for the community as a whole. In this same model, we now see that the institutional resources of all three traditions have the posited negative effect on assault/robbery rates, though the effect is stronger for mainline Protestant and especially Catholic congregations than evangelical Protestant congregations. A one-unit increase in the number of congregations per 100,000 reduces the assault/robbery rate by 1.4 percent for evangelical Protestant congregations, 1.9 percent for mainline Protestant congregations, and 4.7 percent for Catholic congregations.

We highlight that the coefficients in models 1 through 3 are consistent with our hypotheses regarding the effects of adherents and congregations for the three religious traditions, and they reinforce the point that estimating models omitting either measure will conflate the network and institutional effects of these traditions. For instance, since we expect that both congregations and adherents of Catholic and mainline Protestant traditions will have negative effects on crime rates, their coefficients should be larger in models in which only one measure is included. Indeed, we see that the coefficients in model 1 for Catholic and mainline Protestant adherents are larger than those in model 3, where the effects of their congregations are taken into account. Likewise, the coefficients for Catholic and mainline Protestant congregations in model 2 are too large, since they are conflated with the network effects of their adherents. Hence, only model 3 appropriately parses out the effects of the two dimensions of these 
religious traditions: adherents and congregations. Following the same logic, since we posit that evangelical Protestant adherents will have a positive effect on crime in communities while their congregations will generally have a negative effect, these two effects should work in opposition when we include only one measure in the model. This is evident in that while the effect of evangelical Protestant adherents is positive in model 1 , the negative effect of their congregations is not present in model 2. Only in model 3 are we able to separate properly the distinct effects of evangelical Protestant adherents and congregations by including both measures in the same model. ${ }^{9}$

We next test whether bonding and bridging social capital affect the property crime of burglary. We see similar patterns here as those for aggravated assault/robbery. In the model without the congregation variables, Catholic adherents and mainline Protestant adherents are associated with lower burglary rates, while evangelical Protestant adherents are associated with higher burglary rates, as seen in model 4 in Table 2. As with aggravated assault/robbery, mainline Protestant and Catholic congregations are associated with lower rates of crime when measures of adherents are not included in model 5 of Table 2. Our full model shown in model 6 once again is consistent with our predictions. While congregations of all three religious traditions have the expected negative effects on the burglary rates of counties, we again see that only the bridging networks of Catholic and mainline Protestant adherents reduce these rates. A one percentage point increase in either Catholic or mainline Protestant adherents is associated with about a 0.4 percent lower burglary rate. Importantly, we see the hypothesized positive relationship between evangelical Protestant adherents and this crime type. A one percentage point increase in evangelical Protestant adherents is associated with a 0.9 percent increase in the burglary rate. We again note suppressor effects for the evangelical Protestant tradition in the models that do not include both their adherents and congregations.

Finally, we see that the effects of bonding and bridging social capital work similarly for county murder rates. In model 7 with just the measures of adherents, mainline Protestants and evangelical Protestants show the hypothesized effects. The congregations of all three religious traditions have negative effects on murder rates in model 8 , suggesting that they provide important institutional resources to communities. As with the previous two crime outcomes, our full model in model 9 indicates that the 
bridging activity of mainline Protestant adherents has an additional negative effect on county murder rates beyond the institutional effect of their congregations. In contrast, evangelical Protestant adherents are associated with higher rates of murder. For a one standard deviation increase in evangelical Protestant adherents (17 percent), the county's murder rate increases by 13 percent. We emphasize again that our argument is not that evangelical Protestants are committing murders, but rather that their bonding activity gives rise to network structures that make communities as a whole more vulnerable to this and other types of crime.

\section{ALTERNATIVE SPECIFICATIONS AND POSSIBLE COUNTER THEORIES}

A key hypothesis of our study is that the social capital of groups need not always have positive effects for the larger community. In support of this, we found that the proportion of evangelical Protestant adherents — our measure of bonding social capital—was consistently associated with higher crime rates in counties, while the proportion of mainline Protestant and Catholic adherents—our measure of bridging social capital—was generally associated with lower crime rates in counties. However, there may be a concern that by not including general measures of social capital we obtained spurious results. Therefore, we estimated our full models including two measures of general social capital: the number of voluntary organizations in a county and the percentage voting in presidential elections. ${ }^{10}$ Certain scholars (Paxton 1999, 2002; Putnam 2000) have suggested that voluntary organizations reflect the amount of social capital present in a community, while others (Putnam 2000; Rosenfeld et al. 2001) have suggested that voter turnout measures the amount of social capital present in a community. We find that our religious tradition adherent measures of bonding and bridging social capital are generally robust to the inclusion of these two measures of general social capital (see Table A5 in the online appendix at http://www.unc.edu/ johnhipp/religcri.htm). Importantly, adding general social capital does not change our conclusion that bonding social capital is associated with higher community crime rates and bridging social capital is associated with lower community crime rates. ${ }^{11}$

Despite the robustness of our findings, because it is difficult to make causal assertions with crosssectional data, we address the possibility of several important alternative explanations. While there is 
little evidence in our data that mainline Protestants and Catholics are moving to areas where the crime rate is low or that evangelical Protestants are moving to high crime areas, it is possible that a large number of people in high crime areas are evangelical Protestant converts. ${ }^{12}$ While we do not have data on specific individuals for our counties, the General Social Surveys (GSS) allow us to examine this alternative explanation among individuals drawn from a nationally representative sample. For the 198496 time period, we compared the religious tradition of respondents at the time of the survey to when they were $16 .{ }^{13}$ If it is the case that evangelical Protestant converts are disproportionately located in high crime areas, we should find a substantial number of individuals who were not evangelical Protestants at 16 but are now living in high crime areas. As Table 3 shows, our analysis of the GSS does not show a positive relationship between those who converted to evangelical Protestantism and four measures suggestive of high crime areas: fear of walking a mile from one's house at night, experiencing a burglary in the last year, experiencing a robbery in the last year, and community size. In fact, these individuals tend to live in smaller areas and have less fear of walking in their neighborhoods at night. Thus, we find no evidence that individuals living in high crime areas are converting to evangelical Protestantism in substantial numbers.

\section{[INSERT TABLE 3 ABOUT HERE]}

\section{DISCUSSION AND CONCLUSION}

Social capital has become an increasingly popular concept in the social sciences for explaining a range of positive outcomes at various units of analysis. However, a growing number of scholars have begun to criticize this single-minded focus on the positive consequences of social capital, calling for more theoretical and empirical attention to the potential "dark side" of social capital (Fiorina 1999; Paxton 1999, 2002; Portes 1998; Putnam 2000). Responding to this call, we distinguished between bonding and bridging social capital that groups cultivate in communities and explicated how these different types of social capital can have differing effects on crime rates in communities. By generally creating only tightly knit internal network ties among members, bonding groups do not forge ties with others in the wider community, which hinders the flow of communication and collective action efforts in communities and 
thus makes them more susceptible to crime. Bridging groups, however, by creating broadly linked network structures in communities, facilitate the diffusion of information and mobilization of collective resources, reducing the risk of crime.

Importantly, we empirically modeled this specified relationship between bonding and bridging groups and crime in communities. Because of the difficulty of operationalizing bonding and bridging social capital, scholars have tended to conflate these two types of social capital into one combined measure, and thus they have missed the contrasting effects of these types of social capital on communities' crime rates (Messner et al. 2004; Putnam 2000; Rosenfeld et al. 2001). Given the substantial variation in the bonding and bridging activity of America's major religious traditions (see, for instance, Beyerlein and Hipp 2003; Iannaccone 1994; Wilson and Janoski 1995; Wuthnow 1999, 2002), we used measures of adherents of these traditions to represent bonding and bridging network structures in communities. Reflecting these different network structures, our results demonstrated that while a greater percentage of mainline Protestants and Catholics in communities generally lowered rates of various types of crime, a greater percentage of evangelical Protestants in communities consistently increased them. These results were robust to the inclusion of numerous variables shown in previous ecological studies to predict crime rates and to the inclusion of general measures of social capital. Furthermore, in auxiliary analyses, we found consistent patterns when analyzing data from 1980 and 1990 (see note 7). To explain these results, we avoided the ecological fallacy and made no assumption about who were the perpetrators of crimes in communities. Rather, we made a structural argument that the bonding activity of evangelical Protestants creates network structures that make communities as a whole more vulnerable to crime, while the bridging activity of Catholics and mainline Protestants promotes network structures that decrease the risk of crime for communities as a whole.

Despite the difficulty of testing our theoretical model, it points to directions for future research. One especially difficult issue is the geographical unit of analysis. While our study used counties as the unit of analysis, this unit is arguably too large and thus provided a conservative test of our hypotheses. ${ }^{14}$ Measuring bonding and bridging network structures of a community would ideally consist of a multilevel approach in which small neighborhoods are nested within larger areas. In other words, although studies 
focusing on small neighborhoods would miss the important bridging ties that can link residents and groups in small neighborhoods together, studies looking at larger communities face the daunting task of attempting to measure all the ties in these communities. One approach for dealing with this difficulty is to focus on a particular community. While this approach precludes generalizing findings to other areas, several such studies would be able to test the robustness of our theoretical model. There is also the issue of specifying the exact mechanisms through which bonding and bridging social capital influence crime in communities. Future research would benefit from identifying whether collective efficacy mediates the relationship between bonding and bridging social capital and crime rates that we observed (Sampson et al. 1997).

Finally, because we are aware of no other available data on social capital that allow the distinction between bonding and bridging groups to be drawn, we believe that data on adherents of America's major religious traditions are a valuable resource for future explorations of the relationship between social capital and other community-level outcomes. This fact notwithstanding, adherents of American religious traditions are certainly not the only way to operationalize bonding and bridging social capital in communities. For instance, Paxton (2002) adopted a strategy of measuring isolated and connected associational ties of individuals by focusing on the extent to which memberships in organization types overlapped. While her study used this measure in the context of cross-national data on democracy, scholars could adopt this strategy to capture network structures in local communities by specifying whether organization linkages among residents are generally narrow or broad in scope. Although collecting such data presents a challenging task for researchers, our model suggests that other measures that are able to capture the bonding and bridging nature of groups in communities will observe similar effects on crime rates. Regardless of the measurement strategy taken, our conceptual framework provides a useful lens through which to view how the different forms of social capital that groups cultivate in communities can constrain or facilitate outcomes that are desirable for communities as a whole. 


\section{NOTES}

${ }^{1}$ We recognize that very small communities could maintain a bonding network structure in which all residents are strongly linked (Freudenburg 1986). However, this simply is not practical given the typical size of most communities in the United States. Freudenberg (1986) found that strong ties among all residents in communities were extremely unlikely when the population exceeds 5,000 . Since only 10 percent of Americans live in areas with a population smaller than 5,000 (based on census data on "places"), only a very small minority of U.S. residents even live in areas where this is possible.

${ }^{2}$ In their model, Ellison et al. (2003) included a measure of the percent of the population composed of evangelical adherents (log transformed), and a measure of the percent of the population composed of all religious adherents (not log transformed). Since both of these measures change when the percent of evangelical Protestants changes, to interpret the effect of evangelical Protestants requires taking into account the effect of both coefficients simultaneously. The authors did not do this, nor did they test whether there was a statistically significant difference between the effect of evangelical Protestants in southern and non-southern communities. We performed a direct test of this hypothesis with our data by estimating models that included interaction terms between southern and non-southern location and adherents of religious traditions. We found no evidence that evangelical Protestants were associated with higher rates of crime in southern versus non-southern counties for homicide or any other type of crime in 1980, 1990 or 2000 (results available upon request). In fact, our results showed that they were associated with somewhat higher rates of crime in non-southern counties, in direct contrast to Ellison et al.'s (2003) hypothesis.

${ }^{3}$ As is common practice in ecological studies of crime, we averaged our crime measures over these years to minimize fluctuations. While the FBI indicates that crime-reporting units responding to their survey cover over 95 percent of the U.S. population, there are still some fluctuations in the number of units that report for a county in a particular year. In these instances, we calculated crime rates based on the population of the reporting units rather the total population. 
${ }^{4}$ Because auxiliary analyses showed that the effects for these two types of crimes were very similar when separated (results available upon request), combining them does not lose any unique information.

${ }^{5}$ The other religious category includes Jewish, conservative nontraditional (e.g., Christian Scientists or Mormons), liberal nontraditional (e.g., Unitarian-Universalists), Eastern, and African American traditions. Because of a lack of reporting from denominations in the African American tradition, representing this tradition as a separate group is problematic. When we separately tested for the effect of each tradition in the other religious category on crime rates, we found none, which is not surprising given the relatively small percentage of the population for each tradition. We only included the other religious category in our models so the religious traditions of interest would be easily interpretable. Because its heterogeneity renders it substantively meaningfulness, we do not report results for other religious category (it is $\log$ transformed to avoid unduly influential cases given the skewed distribution).

${ }^{6}$ We performed various diagnostic tests to be sure our data conformed to the assumptions of ordinary least squares regression. The inclusion of both adherents and congregations of religious traditions in the same model may raise concerns about collinearity. However, while there is some overlap in the measures of adherents and congregations for each religious tradition in terms of correlations-roughly .77 for evangelical Protestantism, .68 for mainline Protestantism, and .46 for Catholicism—none of the variance inflation factors (VIFs) for these measures were greater than 4, indicating that collinearity was not a cause for concern. This supports the notion that measures of adherents and congregations of religious traditions are not only conceptually distinct, but empirically distinct as well. The largest VIFs for variables in our models were percent white (6.94), percent African American (5.51), and median income (4.97). Models run without these variables were consistent with those presented. We also tested for outliers using Cook's Distance measures. There were never more than five cases in any model that had excessive values and models run dropping these cases were substantively identical to the full models presented.

${ }^{7}$ Data for our measures are also available for 1980 and 1990. Ideally, we would estimate a fixed effects model with the change in religious traditions predicting the change in crime rates over time. 
Unfortunately, data limitations preclude using this approach. The limited variation in the religious tradition measures over time poses serious problems for a fixed effects model. The correlations for the religious tradition measures over time are very high, ranging from .92 to .96 for consecutive years. Because there is reason to suspect that denominations do not necessarily constantly update records for all their members, it is possible that some of this lack of change is due outdated records. Although this error is likely modest in cross-section models and not systematically related to crime, using a fixed effects model would unduly emphasize the presence of this error. Consequently, we estimated a cross-sectional model for all three years of our data. Because the results were substantively similar for all three years, we present only the results for the 2000 models (for results for the 1980 and 1990 models, see Tables A2 and A3 in the online appendix at http://www.unc.edu/ johnhipp/religcri.htm). It is interesting to note that not only did the religious tradition measures show considerable stability over the three time points, but they also exhibited greater stability than the measures identified in the criminology literature as important predictors of community crime.

${ }^{8}$ Since religious tradition adherents are measured as the proportion of the population in the county, the coefficient for each adherent measure always represents the effect on crime for a one percentage point increase in adherents of each religious tradition accompanied by a similar decrease in the reference group (nonreligious adherents). This is analogous to interpretations using $0 / 1$ dummy variables.

${ }^{9}$ A possible alternative explanation is that by including both measures of congregations and adherents in the same model we are simply capturing a "size of congregation" effect. However, the fact that mainline Protestant and evangelical Protestant congregations tend to be of a similar size - the average congregation size in the 1980-2000 Glenmary data is about 215 adherents for evangelical Protestant congregations and 240 adherents for mainline Protestant congregations - and the strikingly different results for their associated coefficients, suggests that this is a less plausible explanation. In addition, despite the fact that the average size of Catholic congregations is much larger (over 1,000 adherents), they do not have a 
stronger effect on reducing crime than mainline Protestants, which is what we would expect if congregation size was driving the effects.

${ }^{10}$ We obtained the voluntary organization data from the National Center for Charitable Statistics (NCCS). This file contains information on tax-exempt organizations from the Internal Revenue Service's Business Master File (BMF). We use data from 2000. The data on voter turnout were for the 1996 Presidential election and were taken from the County and City Databook.

${ }^{11}$ We also tested for possible nonlinear effects of bonding and bridging social capital on crime rates, but found none. We estimated models in which we constructed dummy variables of religious tradition adherents based on 10 percentage point increments (with the maximum category being greater than 60 percent). However, these models showed that the religious tradition effects were consistently linear (see Figures A1-A3 in the online appendix at http://www.unc.edu/ johnhipp/religcri.htm). We also tested for nonlinear compositional effects depending on the group that was decreasing in percentage as a particular group increases in percentage. Combining Catholics and mainline Protestants into a single group of "bridgers," we constructed indicators of counties containing less than 10 percent bridgers, between 10 to 30 percent bridgers, between 30 to 50 percent bridgers, and more than 50 percent bridgers. We constructed four analogous measures for the percentage of "bonders" (evangelical Protestants) in counties, resulting in a $4 \times 4$ cross-classification for religious tradition compositions in counties. These models showed little evidence of interaction effects for the three crime outcomes (see Figures A4-A6 in the online appendix at http://www.unc.edu/ johnhipp/religcri.htm), indicating again that the effects of religious traditions were best modeled as linear.

${ }^{12}$ Our finding of a -.10 correlation between the percentage Catholic and residential mobility in a county and a -.45 correlation between the percentage mainline Protestant and residential mobility is inconsistent with the notion that these groups are moving into low-crime areas. While it is possible that these correlations reflect a scenario where counties with low crime rates and many long-time nonreligious residents are being inundated by large numbers of emigrants from these two religious traditions, we think 
this is rather implausible and know of no supportive evidence (based on individual-level data, for instance, Myers 2000 demonstrated that members of these traditions were less likely to emigrate from areas). It is also logically possible that individuals in low-crime areas are Catholic and mainline Protestant converts. However, we know of no theoretical mechanism or evidence for this argument, so we do not consider it further. By a similar logic, the -.10 correlation between the percentage evangelical Protestant and residential mobility in a county is inconsistent with the notion that adherents of this tradition are moving to high-crime areas.

${ }^{13}$ Because the denomination measures in the GSS were not fine-grained enough to differentiate among Protestant traditions prior to 1984, we only analyzed GSS data after 1984.

${ }^{14} \mathrm{We}$ checked this by estimating our models only for counties with populations less than 30,000 . These smaller counties are closer to the notion of a community. While this subset is not representative of counties as a whole, it is reassuring that we found the same basic patterns for our variables of interest in these smaller units of analysis (results available upon request). 


\section{REFERENCES}

Allison, Paul D. 2002. Missing Data. Thousand Oaks: Sage.

Ammerman, Nancy T. 2002. "Connecting Mainline Protestant Churches with Public Life." Pp. 129-58 in

The Quiet Hand of God, edited by R. Wuthnow and J. H. Evans. Berkeley, CA: University of California Press.

Bellair, Paul E. 1997. "Social Interaction and Community Crime: Examining the Importance of Neighbor Networks." Criminology 35:677-703.

Berk, Richard A. 1983. "An Introduction to Sample Selection Bias in Sociological Data." American Sociological Review 48:386-98.

Beyerlein, Kraig and John R. Hipp. 2003. "From Pews to Participation: The Effect of Congregation Activity and Context on Bridging Civic Engagement." Presented at the annual meeting of the Society for the Scientific Study of Religion, Norfolk, VA.

Chaves, Mark. 2004. Congregations in America. Cambridge, MA: Harvard University Press.

Chaves, Mark, Helen Giesel, and William Tsitsos. 2002. "Religious Variations in Public Presence: Evidence from the National Congregations Study." Pp. 108-28 in Quietly Influential: The Public Role of Mainline Protestantism, edited by R. Wuthnow and J. H. Evans. Berkeley, CA: University of California Press.

Chaves, Mark and William Tsitsos. 2001. "Congregations and Social Services: What They Do, How They Do It, and With Whom." Nonprofit and Voluntary Sector Quarterly 30:660-83.

Cohen, Lawrence E. and Kenneth Land. 1984. "Discrepancies Between Crime Reports and Crime Surveys." Criminology 22:499-530.

Coleman, James S. 1988. "Social Capital in the Creation of Human Capital." American Journal of Sociology 94:S95-S120.

Ellison, Christopher G., Jeffrey A. Burr, and Patricia L. McCall. 2003. "The Enduring Puzzle of Southern Homicide: Is Regional Religious Culture the Missing Piece?" Homicide Studies 7:326-52. 
Evans, T. David, Francis T. Cullen, R. Gregory Dunaway, and Velmer S. Jr. Burton. 1995. "Religion and Crime Reexamined: The Impact of Religion, Secular Controls, and Social Ecology on Adult Criminality." Criminology 33:195-213.

Fiorina, Morris P. 1999. "Extreme Voices: A Dark Side of Civic Engagement." in Civic Engagement in American Democracy, edited by T. Skocpol and M. P. Fiorina. Washington, D.C.: Brookings Institution Press.

Firebaugh, Glenn and Jack P. Gibbs. 1985. "User's Guide to Ratio Variables." American Sociological Review 50:713-22.

Freudenburg, William R. 1986. "The Density of Acquaintanceship: An Overlooked Variable in Community Research?" American Journal of Sociology 92:27-63.

Gove, Walter R., Michael Hughes, and Michael Geerken. 1985. "Are Uniform Crime Reports a Valid Indicator of the Index Crime? An Affirmative Answer with Minor Qualifications." Criminology 23:451-501.

Granovetter, Mark. 1973. "The Strength of Weak Ties." American Journal of Sociology 78:1360-80.

—. 1985. "Economic Action and Social Structure: The Problem of Embeddedness." American Journal of Sociology 91:481-510.

Heckman, James J. 1979. "Sample Selection Bias as a Specification Error." Econometrica 47:153-61.

Hoge, Dean, Charles Zech, Patrick McNamara, and Michael J. Donahue. 1998. "The Value of Volunteers as Resources for Congregations." Journal for the Scientific Study of Religion 37:470-80.

Hurlbert, Jeanne S., Valerie A. Haines, and John J. Beggs. 2000. "Core Networks and Tie Activation: What Kinds of Routine Networks Allocate Resources in Nonroutine Situations?" American Sociological Review 65:598-618.

Iannaccone, Laurence R. 1994. "Why Strict Churches Are Strong." American Journal of Sociology 99:1180-211.

Jacobs, Jane. 1961. The Death and Life of Great American Cities. New York: Random House. 
Johnson, Byron R., Sung Joon Jang, David B. Larson, and De Li Spencer. 2001. "Does Adolescent Religious Commitment Matter? A Reexamination of the Effects of Religiosity on Delinquency." Journal of Research in Crime and Delinquency 38:22-44.

Jones, Dale E., Sherri Doty, Clifford Grammich, James E. Horsch, Richard Houseal, Mac Lynn, John P. Marcum, Kenneth M. Sanchagrin, and Richard H. Taylor. 2002. Religious Congregations \& Membership in the United States 2000: An Enumeration by Region, State and County Based on Data Reported for 149 Religious Bodies. Nashville, TN: Glenmary Research Center.

Kornhauser, Ruth. 1978. Social Sources of Delinquency. Chicago: University of Chicago Press.

Kovandzic, Tomislav V., Lynne M. Vieratis, and Mark R. Yeisley. 1998. "The Structural Covariates of Urban Homicide: Reassessing the Impact of Income Inequality and Poverty in the Post-Reagan Era." Criminology 36:569-99.

Lee, Matthew R. 2000. "Community Cohesion and Violent Predatory Victimization: A Theoretical Extension and Cross-National Test of Opportunity Theory." Social Forces 79:683-706.

Lee, Matthew R. and John P. Bartkowski. 2004. "Love Thy Neighbor? Moral Communities, Civic Engagement, and Juvenile Homicide in Rural Areas." Social Forces 82:1001-35.

Melton, J. Gordon. 2002. Encyclopedia of American Religions. 7th. Detroit: Gale Research Co.

Mesch, Gustavo S. and Kent P. Schwirian. 1996. "The Effectiveness of Neighborhood Collective Action." Social Problems 43:467-83.

Messner, Steven F., Eric P. Baumer, and Richard Rosenfeld. 2004. "Dimensions of Social Capital and Rates of Criminal Homicide." American Sociological Review 69:882-903.

Morenoff, Jeffrey D. and Robert J. Sampson. 1997. "Violent Crime and The Spatial Dynamics of Neighborhood Transition: Chicago, 1970-1990." Social Forces 76:31-64.

Myers, Scott M. 2000. "The Impact of Religious Involvement on Migration." Social Forces 79:755-83.

Paxton, Pamela. 1999. "Is Social Capital Declining in the United States? A Multiple Indicator Assessment." American Journal of Sociology 105:88-127.

—. 2002. "Social Capital and Democracy: An Interdependent Relationship." American Sociological Review 67:254-77. 
Pong, Suet-ling. 1998. "The School Compositional Effect of Single Parenthood on 10th-Grade Achievement." Sociology of Education 71:24-43.

Portes, Alejandro. 1998. "Social Capital: Its Origins and Applications in Modern Sociology." Annual Review of Sociology 22:1-24.

Putnam, Robert D. 2000. Bowling Alone: The Collapse and Revival of American Community. New York: Simon \& Schuster.

Rosenfeld, Richard, Steven F. Messner, and Eric P. Baumer. 2001. "Social Capital and Homicide." Social Forces 80:283-309.

Sampson, Robert J. and W. Byron Groves. 1989. "Community Structure and Crime: Testing SocialDisorganization Theory." American Journal of Sociology 94:774-802.

Sampson, Robert J., Jeffrey D. Morenoff, and Felton Earls. 1999. "Beyond Social Capital: Spatial Dynamics of Collective Efficacy for Children." American Sociological Review 64:633-60.

Sampson, Robert J. and Stephen W. Raudenbush. 1999. "Systematic Social Observation of Public Spaces: A New Look at Disorder in Urban Neighborhoods." American Journal of Sociology 105:603-51.

Sampson, Robert J., Stephen W. Raudenbush, and Felton Earls. 1997. "Neighborhoods and Violent Crime: A Multilevel Study of Collective Efficacy." Science 277:918-24.

Schafer, Joseph L. and John W. Graham. 2002. "Missing Data: Our View of the State of the Art." Psychological Methods 7:147-77.

Shaw, Clifford and Henry D. McKay. 1942. Juvenile Delinquency and Urban Areas. Chicago: University of Chicago Press.

Sloane, Douglas M. and Raymond H. Potvin. 1986. "Religion and Delinquency: Cutting Through the Maze." Social Forces 65.

Stark, Rodney. 1996. "Religion as Context: Hellfire and Delinquency One More Time." Sociology of Religion 57:163-73.

Stark, Rodney, Lori Kent, and Daniel Doyle. 1982. "Religion and Delinquency: The Ecology of a "Lost" Relationship." Journal of Research in Crime and Delinquency 19:4-24. 
Steensland, Brian, Jerry Z. Park, Mark D. Regnerus, Lynn D. Robinson, W. Bradford Wilcox, and Robert D. Woodberry. 2000. "The Measure of American Religion: Toward Improving the State of the Art." Social Forces 79:291-318.

Taylor, Ralph B., Stephen D. Gottfredson, and Sidney Brower. 1984. "Block Crime and Fear: Defensible Space, Local Social Ties, and Territorial Functioning." Journal of Research in Crime and Delinquency 21:303-31.

Tolbert, Charles M, Thomas A Lyson, and Michael D Irwin. 1998. "Local capitalism, civic engagement, and socioeconomic well-being." Social Forces 77:401-27.

Wilcox, W. Bradford. 2004. Soft Patriarchs, New Men: How Christianity Shapes Fathers and Husbands. Chicago: University of Chicago.

Wilson, John and Thomas Janoski. 1995. "The Contribution of Religion to Volunteer Work." Sociology of Religion 56:137-52.

Wuthnow, Robert. 1999. "Mobilizing Civic Engagement: The Changing Impact of Religious Involvement." Pp. 331-63 in Civic Engagement in American Democracy, edited by T. Skocpol and M. P. Fiorina. Washington, D.C.: Brookings Institution.

—. 2002. "Beyond Quiet Influence? Possibilities for the Protestant Mainline." in The Quiet Hand of God: Faith-Based Activism and the Public Role of Mainline Protestantism, edited by R. Wuthnow and J. H. Evans. Berkeley, CA: University of California Press.

- 2004. Saving America? Princeton, NJ: Princeton University Press. 
TABLE 1: Descriptive Statistics for 2000 County Variables Used in Analysis

Crime types

Aggravated assaults/robberies per 100,000, logged

Mean Std. Dev.

Burglaries per 100,000, logged

Murders per 100,000, logged

Adherents

Proportion evangelical Protestants

Proportion mainline Protestants

Proportion Catholics

Proportion other religious adherents, logged

Congregations

Evangelical Protestant congregations per 100,000

Mainline Protestant congregations per 100,000

Catholic congregations per 100,000

Other Congregations per 100,000

Control Variables

$1 /$ population

Population density per kilometer (divided by 10,000)

Percent with bachelor's degree or greater

5.08

1.20

$6.15 \quad .90$

.95

Percent at or below the poverty level

Median Household income

Percent African-American

Percent Latino

.23

.17

$.14 \quad .11$

$.14 \quad .15$

$-6.11 \quad 2.96$

$11.69 \quad 8.59$

$7.52 \quad 6.81$

$1.99 \quad 3.56$

$.91 \quad 2.64$

Percent white

$.95 \quad 3.39$

$.09 \quad .64$

$16.50 \quad 7.80$

$14.18 \quad 6.56$

$35,321 \quad 8,956$

$8.62 \quad 14.45$

$6.13 \quad 12.06$

$81.30 \quad 19.14$

Unemployment rate

$\begin{array}{ll}5.83 & 2.87\end{array}$

Residential instability (average length of residence)

$3.86 \quad .30$

Percent single parents

$11.70 \quad 3.88$

South

Note : $\mathrm{N}=3,157$ 
TABLE 2: Unstandardized Coefficients from the Regression of Various Crime Types on Religious Tradition Adherents and Congregations, Controlling for Demographic Factors

\begin{tabular}{|c|c|c|c|c|c|c|c|c|c|}
\hline & (1) & (2) & (3) & (4) & (5) & (6) & (7) & (8) & (9) \\
\hline & $\begin{array}{l}\text { Assault/ } \\
\text { Robbery }\end{array}$ & $\begin{array}{l}\text { Assault/ } \\
\text { Robbery }\end{array}$ & $\begin{array}{l}\text { Assault/ } \\
\text { Robbery }\end{array}$ & Burglary & Burglary & Burglary & Murder & Murder & Murder \\
\hline \multicolumn{10}{|l|}{ Adherents (a) (b) } \\
\hline Evangelical Protestants & $\begin{array}{l}.760 * * \\
(.130)\end{array}$ & & $\begin{array}{l}.923 * * \\
(.180)\end{array}$ & $\begin{array}{l}.634 \text { ** } \\
(.110)\end{array}$ & & $\begin{array}{l}.883 * * \\
(.152)\end{array}$ & $\begin{array}{l}.326 \text { ** } \\
(.096)\end{array}$ & & $\begin{array}{l}.740 \text { ** } \\
(.143)\end{array}$ \\
\hline Mainline Protestants & $\begin{array}{l}-1.812 * * \\
(.188)\end{array}$ & & $\begin{array}{l}-1.298 * * \\
(.234)\end{array}$ & $\begin{array}{l}-.721 * * \\
(.162)\end{array}$ & & $\begin{array}{l}-.410 * \\
(.205)\end{array}$ & $\begin{array}{l}-.427 * * \\
(.144)\end{array}$ & & $\begin{array}{l}-.391 * \\
(.189)\end{array}$ \\
\hline Catholics & $\begin{array}{l}-.291 \dagger \\
(.161)\end{array}$ & & $\begin{array}{l}-.236 \\
(.172)\end{array}$ & $\begin{array}{l}-.286 * \\
(.132)\end{array}$ & & $\begin{array}{l}-.426 * * \\
(.145)\end{array}$ & $\begin{array}{r}.057 \\
(.110)\end{array}$ & & $\begin{array}{l}-.119 \\
(.123)\end{array}$ \\
\hline \multicolumn{10}{|l|}{ Congregations (c) } \\
\hline Evangelical Protestants & & $\begin{array}{r}.001 \\
(.003)\end{array}$ & $\begin{array}{l}-.014 * * \\
(.004)\end{array}$ & & $\begin{array}{r}.001 \\
(.002)\end{array}$ & $\begin{array}{l}-.014 * * \\
(.003)\end{array}$ & & $\begin{array}{l}-.009 * * \\
(.002)\end{array}$ & $\begin{array}{l}-.020 * * \\
(.003)\end{array}$ \\
\hline Mainline Protestants & & $\begin{array}{l}-.038 * * \\
(.004)\end{array}$ & $\begin{array}{l}-.019 * * \\
(.005)\end{array}$ & & $\begin{array}{l}-.022 * * \\
(.003)\end{array}$ & $\begin{array}{l}-.014 * * \\
(.004)\end{array}$ & & $\begin{array}{l}-.016 * * \\
(.003)\end{array}$ & $\begin{array}{l}-.008 \dagger \\
(.004)\end{array}$ \\
\hline Catholics & & $\begin{array}{l}-.057 * * \\
(.007)\end{array}$ & $\begin{array}{l}-.047 * * \\
(.007)\end{array}$ & & $\begin{array}{l}-.029 * * \\
(.006)\end{array}$ & $\begin{array}{l}-.017 * * \\
(.006)\end{array}$ & & $\begin{array}{l}-.025 * * \\
(.006)\end{array}$ & $\begin{array}{l}-.018 * * \\
(.006)\end{array}$ \\
\hline$\underline{\mathrm{R}^{2}}$ & .48 & .48 & .50 & .30 & .31 & .32 & .37 & .39 & .40 \\
\hline
\end{tabular}

(a): reference group is percent nonreligious. (b): measured as percent of county population; (c): measured as number of congregations per 100,000 population

Note: Numbers in parentheses are standard errors; $\mathrm{N}=3,157$. All models include measures of inverse population, population density, education, poverty, median income, median income squared, African-American, Latino, white, unemployment rate, residential instability, single parents, south, and other religious adherents and congregations

$* * \mathrm{p}<.01$ (two-tail test), $* \mathrm{p}<.05$ (two-tail test), $\dagger \mathrm{p}<.05$ (one-tail test). 
TABLE 3: T-Tests Comparing Evangelical Protestant Converts to Lifelong Evangelical Protestants Concerning Crime Exposure

\begin{tabular}{lrrr}
\hline & \multicolumn{2}{c}{ Means } & Sig. \\
\cline { 2 - 4 } & $\begin{array}{c}\text { Lifelong } \\
\text { Evangelical } \\
\text { Protestants }\end{array}$ & $\begin{array}{c}\text { Converted } \\
\text { Evangelical } \\
\text { Protestants }\end{array}$ & \\
\cline { 2 - 4 } Fear of walking in neighborhood & .418 & .395 & $-2.42 *$ \\
Experience burglary in the last year & .064 & .059 & .84 \\
Experience robbery in the last year & .020 & .018 & .42 \\
Size of place (1,000's) & 385.050 & 291.640 & $5.46 * *$ \\
& & & \\
Note: N's range from 19,670 to 36,551 & & &
\end{tabular}

